\title{
The Analysis of Quality of Work Life and Work Achievement in Department of Agriculture Simalungun Regency
}

\author{
Nur M. Ridha Tarigan', Rahmat Akbar Syahputra ${ }^{2}$, Tri Kartika Yudha ${ }^{3}$ \\ ${ }^{1,2,3}$ Universitas Islam Negeri Sumatera Utara, Indonesia
}

\section{Abstract}

In fact, the work performance of employees does not match the expectations of an agency, and they still encounter low employee performance. As a result of low employee performance, the impact on agency productivity decreases and cannot meet the targets set by the agency, so that the agency suffers losses and experiences obstacles in its development. Meanwhile, for employees who have low work performance, it will hinder the career development and income of the employee.Descriptive analysis is a research method that provides an overview regarding situations and events so that this method intends to Base data accumulation applies.From the results of the analysis with the number of respondents as many as 63 people, the following conclusions are drawn: 1) Job satisfaction has a positive and significant effect on employee performance in Simalungun Regency Agriculture Office. 2) Leaders are expected to improve the promotion appraisal system based on performance and work results. 3) Maintaining the current good condition of employees, who are able to work hard to get awards, a welldeveloped family atmosphere and an interesting and challenging work atmosphere has been created.

\section{Keywords}

work life; work

achievement; department of agriculture

\section{Introduction}

Human resources are one of the elements in the agency that have an important role for the continuity of the agency, so that the progress of an agency depends on the roles performed by the people in it. No matter how sophisticated the tools and work facilities owned by the agency, but without a human work function, the existence of the agency will not mean anything, this is because humans have the ability in the form of energy and mind to do something useful for the agency.

The role of human resources in an agency is no less important than other resources such as capital, investment and technology. Because other resources cannot provide benefits if they are not managed by human resources. Human resources are one of the main supporting pillars of the agency to move the wheels of an agency in an effort to realize the mission and vision of the agency. Human resources in an organization need to be managed professionally in order to achieve a balance between the needs of employees and the demands and capabilities of the organization. This balance is the main key for an organization to be able to develop productively and naturally.

Employee performance is very important for an agency to achieve its goals, this is because each agency is basically established to get the maximum profit. Agencies must be able to use their human resources as much as possible, in this case the available employees to achieve these goals. Employee performance in an agency occupies a strategic position, because good employee performance can be a driving force to achieve agency goals. On the other hand, poor employee performance can be an obstacle in achieving agency goals. 
In fact, the work performance of employees does not match the expectations of an agency, and they still encounter low employee performance. As a result of low employee performance, the impact on agency productivity decreases and cannot meet the targets set by the agency, so that the agency suffers losses and experiences obstacles in its development. Meanwhile, for employees who have low work performance, it will hinder the career development and income of the employee.

Mangkunegara (2011:117) defines job satisfaction as a feeling that supports or does not support an employee related to his work or his condition. Job satisfaction is a reflection of workers' feelings towards their work. This can be seen in the positive attitude of workers towards the work at hand and the environment. On the other hand, dissatisfied employees will have a negative attitude towards their work and environment in different forms. The existence of employee job dissatisfaction should be detected by the agency.

Work performance is the result that can be achieved by a person in doing the work that is his duty and all these results will be assessed by the company or his superiors. Employee work performance can only be grown if the work climate attracts the workers who are needed, feel at home and are willing to exert all their abilities at work. Based on the phenomena and observations mentioned above, the researchers are interested in conducting research on "The Analysis of Quality of Work Life and Work Achievement in the Simalungun Regency Agriculture Office".The failure of the church in carrying out its mission led to the rise of ancestor worship for Toba Bataks.

Financial statements are basically a source of information for investors as one of the basic considerations in making capital market investment decisions and also as a means of management responsibility for the resources entrusted to them (Prayoga and Afrizal 2021) . Financial performance is a measuring instrument to know the process of implementing the company's financial resources. It sees how much management of the company succeeds, and provides benefits to the community. Sharia banking is contained in the Law of the Republic of Indonesia No.21 of 2008 article 5, in which the Financial Services Authority is assigned to supervise and supervise banks. (Ichsan, R. et al. 2021)

This study aims to analyze Samosir Regency in the Development of Monument in depth, comprehensively and holistically in the life of the modern Toba Batak people who have embraced religion today.

\section{Review of Literature}

\subsection{Job Satisfaction}

Each individual working in a setevery organization is appropriate expect to get segsomething useful and profitable for himself. On dbasically job satisfaction is the thing that individual will have a level ofdifferent fasts according to with the value system that applies to him. Their views on working environment conditions and feelings of satisfaction aknow not satisfied with the condition this will affect their behavior at work.

Job satisfaction proposed by Kreitner and Kinicki (2014: 271) is an effectiveness or emotional response to various aspects of work. Satisfaction is not a single concept, on the contrary, a person can be relatively satisfied with one aspect of his job and dissatisfied with one or more other aspects.

Furthermore, Kreitner \& Kinicki (2014: 271) explain that five prominent satisfaction models will classify the causes, as follows:

1. Fulfillment

This model explains that satisfaction is determined by the characteristics of a job that allows an individual to fulfill his needs. For example, a recent survey of 30 Massachusetts 
legal aid agencies revealed that $35 \%$ to $50 \%$ of legal aid partners left the agency in the first three years because the agency did not accommodate family needs.

This example illustrates that unmet needs can affect employee satisfaction or termination. Although these models raise controversy, it is generally accepted that need fulfillment has a correlation with job satisfaction.

\section{Incompatibility.}

These models explain that satisfaction is the result of expectations being met. Satisfied expectations represent the difference between what an individual expects from a job, such as good pay and promotion opportunities, and what is in fact always received. When expectations are greater than received, a person will be dissatisfied. On the other hand, this model predicts that the individual will be satisfied when he maintains the output he receives beyond his own personal expectations. In other words, fulfilled expectations are significantly related to job satisfaction.

\section{Value achievement.}

The idea underlying value achievement is that satisfaction stems from and the perception that a job allows for the fulfillment of an individual's important work values.

\section{Equality.}

In this model, satisfaction is a function and how an individual is treated "fairly" in the workplace. Satisfaction comes from a person's perception that the output of work is relatively the same as the input. It means that perceived fairness of wages and promotions is significantly correlated with job satisfaction.

\section{Components of genetic traits.}

This model is based on the belief that job satisfaction is part of a personal trait as well as genetic factors. This model suggests that stable individual differences are as important in explaining job satisfaction as the characteristics of the work environment. Although few studies have tested this claim, the results show a positive and significant relationship between personal/genetic traits and job satisfaction.

\subsection{Impact of Job Satisfaction and Job Dissatisfaction}

The impact that arises from job satisfaction or the influence of job satisfaction, Robbins (2013: 251) describes this as follows:

1. Satisfaction and productivity.

Job satisfaction has a positive relationship with productivity, meaning that high job satisfaction will increase employee productivity. This relationship will be strong if employees are not influenced by external factors. The level of work also affects the strength of the relationship between job satisfaction and productivity. Research shows that a strong relationship is seen in employees with higher job levels, for example for managerial positions.

2. Job satisfaction and turnover.

The relationship between job satisfaction and turnover is negative, with the strength of the relationship being moderate or not too strong and not too weak. There are other factors that have a role in determining the relationship between job satisfaction and turnover such as age, commitment to the organization, general economic conditions, and labor market conditions. Robbins added employee performance factor as one of the intermediate variables that affect the strength of the relationship between 
satisfaction and turnover, because organizations tend to retain their best employees with various kinds of compensation so that employees feel satisfied.

3. Job satisfaction with the level of absenteeism (absenteeism)

The negative relationship between job satisfaction and absenteeism has a weaker strength when compared to the relationship between job satisfaction and turnover. The strength of the relationship is influenced by the employee's feelings towards the work he holds, namely whether he feels his work is important or not. Another influential factor is if the organization has a policy to reduce wages if employees are not present.

\subsection{How to Increase Job Satisfaction}

Basically there are several causes of dissatisfaction from employees or work groups in a company, for example due to poor supervision levels, low working conditions, conflicts between co-workers, with superiors or subordinates, lack of security, limited opportunities for advancement and work. Which is felt to be inappropriate.

Wexley and Yulk in Mangkunegara (2011:134) there are several connecting approaches with steps to overcome problems and improve a sense of job dissatisfaction, if the causative factors have been known beforehand, as for lanare the steps as follows:

1. Changing working conditions, salary or job design, depending on the factors causing it.

2. Transferring the employee to another field of work so that the characteristics of the employee match the job.

3. Trying to change the perception of employees who experience a sense of job dissatisfaction.

Job satisfaction needs attention because job satisfaction seems to reduce absenteeism, employee turnover and the rate of accidents that occur. In the end, good placement activities will help to overcome and improve feelings of dissatisfaction.

\subsection{Job Satisfaction Indicator}

Research from Spector in Priansa (2016: 292) states that job satisfaction is related to how employees feel about their work and to various aspects of the job, so job satisfaction is closely related to the extent to which employees are satisfied or dissatisfied with their work. And he can identify job satisfaction indicators from nine aspects, namely:

1. Wages

This aspect measures employee satisfaction with respect to the salary they receive and the increase in salary, namely the amount of salary received in accordance with the level that is considered commensurate. Wages and salaries do have an influence on job satisfaction. Wages and salaries also describe various dimensions of job satisfaction. Employees view salary as a right that they must receive for the obligations they have carried out.

2. Promotion

This aspect measures the extent to which employee satisfaction relates to promotion policies and opportunities for promotion. Promotions or opportunities to improve careers also have an influence on employee job satisfaction. Employees will see whether the organization provides equal opportunities to every employee to get a promotion or is it only for some people. This promotion policy must be carried out fairly, i.e. every employee who does a good job has the same opportunity for promotion. 


\subsection{Quality of Work Life}

Cascio in Avianti and Kartika (2017:7), defines the quality of work life into two views, the first view states that the quality of work life, a set of circumstances and practices and organizational goals (for example: job enrichment, internal promotion policies, democratic supervision, employee participation and safe working conditions). Meanwhile, the second view defines the quality of work life as employee perceptions such that employees feel safe, relatively satisfied and get the opportunity to grow and develop like humans.

According to Siagian in Irawati (2015:42), states that, as a concept the quality of work life can be said as a systematic effort in organizational life through which workers are also given the opportunity to find their way of working and which they provide to the organization in order to achieve its goals and various objectives.

\subsection{Purpose of Implementing Quality of Work Life}

The main objectives in implementing the quality of work life are:

1. Improved working conditions (especially from an employee perspective) and greater organizational effectiveness. A balanced situation between the company and employees can increase job satisfaction and employee productivity.

2. Reduction of absenteeism of employees, low number of employees moving/leaving and can increase employee job satisfaction.

3. Quality of work life only contributes to the organization's ability to recruit quality employees but also makes the company more competitive.

\subsection{Application Advantage Quality of Work Life}

According to Davis and Newstrom in Paseki (2013:1242) Quality of work life refers to whether the work environment is pleasant or not for people. For workers, the application of principles that pay attention to the quality of work life can provide several benefits such as ensuring their welfare, having a good working climate and conditions and ultimately bringing a psychological impact on the employees themselves.

For an agency or organization to attract and retain qualified workers into a company, it is necessary to implement a quality of work life program so that it is expected to:

1. Promote or create more democratic organizations where all members of the organization have the opportunity to vote on decisions that affect their democratic participation in the workplace.

2. Distribute financial rewards fairly.

3. Improving job security, by increasing organizational vitality and enforcing employee rights.

4. Improving personnel development by creating conditions that lead to growth and development (Cherington).

\subsection{Work Performance}

Work performance is an achievement of the results obtained by someone at work. Not everyone's work performance is the same because the attitudes and traits and thoughts of each person are clearly different.

Hasibuan (2016: 94) says that work performance is a work achieved by a person in carrying out the tasks assigned to him based on skills, experience and sincerity and time.

According to Mangkunegara (2013: 67), work performance is the result of work in quality and quantity achieved by an employee in carrying out his duties in accordance with the responsibilities given to him. 
Lawler (2011: 88) states that work performance can be defined as a result achieved by employees in carrying out their duties or work efficiently and effectively.

From the definitions above, it can be concluded that the size of the level of work performance of an employee can be measured based on the ability and acceptance of the explanation of the delegation of tasks and roles as well as the level of motivation of an employee as well as the abilities and interests of employees. The higher it is, the greater the level of achievement of an employee concerned.

\section{Research Methods}

Descriptive analysis is a research method Frequency de Weight view regarding situations and events so that this method inten Frequency $\mathrm{d}_{i}$ iulation applies. According to Sugiyono (2013: 53) descriptive research is a research conducted to determine the value of the independent variable, both one and more (independent) variables without making comparisons or relate to other variables. The variables of this research are job satisfaction, quality of work life and work performance. The results of distributing the questionnaire then look for the average by using the formula from Husein Umar (2011:130) namely:

$$
\text { Average Score }=\frac{\sum \text { Frekuensi } \times \text { Bobot }}{\sum \text { Population }}
$$

After the average score is calculated, then to categorize classify the tendency of respondents' answers into a scale with formulation as follows:

Minimum score $=1$

Maximum score $=5$

$$
\begin{aligned}
& \text { Scale Width }=\frac{\text { Maximum Score }- \text { Minimum Score }}{\text { Maximum Score }} \\
& \text { Scale Width }:=\frac{5-1}{5} \\
& \text { Scale Width }:=0,8
\end{aligned}
$$

\section{Research and Discussion}

\subsection{Respondlent Identity}

Questionnaires distributed to respondents or employees in Simalungun Regency Agriculture Officetotaled 63 people. In the following, the researcher will describe the identity of the respondents based on their gender, and the level of education of the respondents.

\subsection{Identity of Respondents by Gender}

Table 1. Identity of Respondents by Gender

\begin{tabular}{||c|c|c|c||}
\hline No & Gender & Amount & Percentage \\
\hline 1 & Man & 36 & $57.14 \%$ \\
\hline 2 & Woman & 27 & $42.86 \%$ \\
\hline \multicolumn{2}{|c|}{ T total } & $\mathbf{6 3}$ & $\mathbf{1 0 0 \%}$ \\
\hline
\end{tabular}

Source: Simalungun Regency Agriculture Office 2020 
Based on table 1 above, the majority of respondents with male gender are 36 people $(57.14 \%)$ and 27 female respondents $(42.86 \%)$.

\subsection{Respondent Identity Based on Education}

Based on table 2 below, respondents with a high school level education totaled 14 people (22.22\%), Diploma amounted to 1 person (1.59\%), Bachelor totaled 43 people $(68.25 \%)$, and 5 postgraduates (7.94\%).

Table 2. Respondent Identity Based on Education

\begin{tabular}{||c|l|c|c||}
\hline No & \multicolumn{1}{|c|}{ Education } & Amount & Percentage \\
\hline 1 & high school & 14 & $22.22 \%$ \\
\hline 2 & Diploma III & 1 & $1.59 \%$ \\
\hline 3 & Bachelor degree) & 43 & $68.25 \%$ \\
\hline 4 & Postgraduate & 5 & $7.94 \%$ \\
\hline \multicolumn{2}{|c|}{ T total } & $\mathbf{6 3}$ & $\mathbf{1 0 0 . 0 0 \%}$ \\
\hline
\end{tabular}

Source: Simalungun Regency Agriculture Office 2020

\subsection{Identity of Respondents by Group/Rank}

Based on table 3 below, respondents with the rank of supervisor, IV-a amounted to 7 person (11.11\%), Kindergarten 1, III-d total 15 person (23.81\%), Stylist, III-c total 13 person $(20.63 \%)$, Tk.1, III-b Young stylists amounted to 5 person (7.94\%), Young Stylist, III-a total 9 person (14.29\%), Regulating TK.I, II-d amounted to 2 person $(3.17 \%)$, Regulating, II-c amounted to 9 person (14.29\%), and Young Regulators, II-a total 9 person $(14.29 \%)$.

Table 3. Respondent Identity Based on Group/Rank

\begin{tabular}{|c|l|c|c||}
\hline \hline No & \multicolumn{1}{|c|}{ Group/Rank } & Amount & Percentage \\
\hline 1 & Trustees, IV-a & 7 & $11.11 \%$ \\
\hline 2 & Kindergarten 1, III-d & 15 & $23.81 \%$ \\
\hline 3 & Stylist, III-c & 13 & $20.63 \%$ \\
\hline 4 & Young Stylists Kindergarten, III-b & 5 & $7.94 \%$ \\
\hline 5 & Young Stylist, III-a & 9 & $14.29 \%$ \\
\hline 6 & TK.I, II-d organizer & 2 & $3.17 \%$ \\
\hline 7 & Regulator, II-c & 9 & $14.29 \%$ \\
\hline 8 & Young Registrar, II-a & 3 & $4.76 \%$ \\
\hline \multicolumn{2}{|c|}{ Total } & $\mathbf{6 3}$ & $\mathbf{1 0 0 . 0 0 \%}$ \\
\hline
\end{tabular}

Source: Simalungun Regency Agriculture Office 2020 
Table 4. Respondents' Answers on Job Satisfaction (X1)

\begin{tabular}{|c|c|c|c|c|c|c|c|c|c|c|c|c|}
\hline \multirow{3}{*}{ No } & \multicolumn{12}{|c|}{ "ANSWER } \\
\hline & \multicolumn{2}{|r|}{ SS } & \multicolumn{2}{|r|}{$\bar{S}$} & \multicolumn{2}{|c|}{ KS } & \multicolumn{2}{|c|}{$\overline{T S}$} & \multicolumn{2}{|c|}{ STS } & \multicolumn{2}{|c|}{ Amount } \\
\hline & $\mathbf{F}$ & $\%$ & $\mathbf{F}$ & $\%$ & $\bar{F}$ & $\%$ & $\mathbf{F}$ & $\%$ & $\mathbf{F}$ & $\%$ & $\mathbf{F}$ & $\%$ \\
\hline 1 & 14 & $22.2 \%$ & 49 & $77.8 \%$ & 0 & $0.0 \%$ & 0 & $0.0 \%$ & 0 & $0.0 \%$ & 63 & $100.0 \%$ \\
\hline 2 & 5 & $7.9 \%$ & 56 & $88.9 \%$ & 2 & $3.2 \%$ & 0 & $0.0 \%$ & 0 & $0.0 \%$ & 63 & $100.0 \%$ \\
\hline 3 & 14 & $22.2 \%$ & 49 & $77.8 \%$ & 0 & $0.0 \%$ & 0 & $0.0 \%$ & 0 & $0.0 \%$ & 63 & $100.0 \%$ \\
\hline 4 & 5 & $7.9 \%$ & 56 & $88.9 \%$ & 2 & $3.2 \%$ & 0 & $0.0 \%$ & 0 & $0.0 \%$ & 63 & $100.0 \%$ \\
\hline 5 & 5 & $7.9 \%$ & 56 & $88.9 \%$ & 2 & $3.2 \%$ & 0 & $0.0 \%$ & 0 & $0.0 \%$ & 63 & $100.0 \%$ \\
\hline 6 & 33 & $52.4 \%$ & 30 & $47.6 \%$ & 0 & $0.0 \%$ & 0 & $0.0 \%$ & 0 & $0.0 \%$ & 63 & $100.0 \%$ \\
\hline 7 & 5 & $7.9 \%$ & 56 & $88.9 \%$ & 2 & $3.2 \%$ & 0 & $0.0 \%$ & 0 & $0.0 \%$ & 63 & $100.0 \%$ \\
\hline 8 & 5 & $7.9 \%$ & 56 & $88.9 \%$ & 2 & $3.2 \%$ & 0 & $0.0 \%$ & 0 & $0.0 \%$ & 63 & $100.0 \%$ \\
\hline 9 & 14 & $22.2 \%$ & 49 & $77.8 \%$ & 0 & $0.0 \%$ & 0 & $0.0 \%$ & 0 & $0.0 \%$ & 63 & $100.0 \%$ \\
\hline Average & 11 & $17.6 \%$ & 51 & $80.6 \%$ & 1 & $1.8 \%$ & 0 & $0.0 \%$ & 0 & $0.0 \%$ & 63 & $100.0 \%$ \\
\hline
\end{tabular}

Source: Research Results 2020

In table 4 above, are respondents' answers to the indicators of job satisfaction variables at the Simalungun Regency Agriculture Office. On average, it can be seen that the respondents' answers are $17.6 \%$ strongly agree, $80.6 \%$ agree and $1.8 \%$ disagree.

\subsection{Respondents' Answers on Quality of Work Life (X2)}

In table 5 below, are respondents' answers to the indicators of the quality of work life variable at the Simalungun Regency Agriculture Service. On average, it can be seen that the respondents' answers are $32.3 \%$ strongly agree, $63.8 \%$ agree, and 3.9\% disagree.

Table 5. Respondents' Answers on Quality of Work Life (X2)

\begin{tabular}{|c|c|c|c|c|c|c|c|c|c|c|c|c|}
\hline \multirow{3}{*}{ No } & \multicolumn{12}{|c|}{ ANSWER } \\
\hline & \multicolumn{2}{|r|}{ SS } & \multicolumn{2}{|r|}{$\mathbf{S}$} & \multicolumn{2}{|r|}{ KS } & \multicolumn{2}{|c|}{ TS } & \multicolumn{2}{|c|}{ STS } & \multicolumn{2}{|c|}{ Amount } \\
\hline & $\mathbf{F}$ & $\%$ & $\mathbf{F}$ & $\%$ & $\mathbf{F}$ & $\%$ & $\mathbf{F}$ & $\%$ & $\mathbf{F}$ & $\%$ & $\mathbf{F}$ & $\%$ \\
\hline 1 & 16 & $25.4 \%$ & 47 & $74.6 \%$ & 0 & $0.0 \%$ & 0 & $0.0 \%$ & 0 & $0.0 \%$ & 63 & $100.0 \%$ \\
\hline 2 & 14 & $22.2 \%$ & 33 & $52.4 \%$ & 16 & $25.4 \%$ & 0 & $0.0 \%$ & 0 & $0.0 \%$ & 63 & $100.0 \%$ \\
\hline 3 & 29 & $46.0 \%$ & 31 & $49.2 \%$ & 3 & $4.8 \%$ & 0 & $0.0 \%$ & 0 & $0.0 \%$ & 63 & $100.0 \%$ \\
\hline 4 & 13 & $20.6 \%$ & 50 & $79.4 \%$ & 0 & $0.0 \%$ & 0 & $0.0 \%$ & 0 & $0.0 \%$ & 63 & $100.0 \%$ \\
\hline 5 & 13 & $20.6 \%$ & 50 & $79.4 \%$ & 0 & $0.0 \%$ & 0 & $0.0 \%$ & 0 & $0.0 \%$ & 63 & $100.0 \%$ \\
\hline 6 & 36 & $57.1 \%$ & 27 & $42.9 \%$ & 0 & $0.0 \%$ & 0 & $0.0 \%$ & 0 & $0.0 \%$ & 63 & $100.0 \%$ \\
\hline 7 & 13 & $20.6 \%$ & 47 & $74.6 \%$ & 3 & $4.8 \%$ & 0 & $0.0 \%$ & 0 & $0.0 \%$ & 63 & $100.0 \%$ \\
\hline 8 & 13 & $20.6 \%$ & 50 & $79.4 \%$ & 0 & $0.0 \%$ & 1 & $1.6 \%$ & 0 & $0.0 \%$ & 64 & $101.6 \%$ \\
\hline 9 & 36 & $57.1 \%$ & 27 & $42.9 \%$ & 0 & $0.0 \%$ & 0 & $0.0 \%$ & 0 & $0.0 \%$ & 63 & $100.0 \%$ \\
\hline Average & 20 & $32.3 \%$ & 40 & $63.8 \%$ & 2 & $3.9 \%$ & 0 & $0 \%$ & 0 & $0 \%$ & 63 & $100.2 \%$ \\
\hline
\end{tabular}

Source: Research Results 2020 


\subsection{Respondents' Answers on Work Performance (Y)}

In the following table 6 , are respondents' answers to the indicators of work performance variables at the Simalungun Regency Agriculture Service. On average, it can be seen that the respondents' answers are $21.7 \%$ strongly agree, $53.3 \%$ agree, and as much as $25.0 \%$ disagree.

Table 6. Respondents' Answers on Work Performance (Y)

\begin{tabular}{|c|c|c|c|c|c|c|c|c|c|c|c|c|}
\hline \multirow{3}{*}{ No } & \multicolumn{12}{|c|}{ ב ANSWER } \\
\hline & \multicolumn{2}{|r|}{ SS } & \multicolumn{2}{|r|}{$\mathbf{S}$} & \multicolumn{2}{|r|}{ KS } & \multicolumn{2}{|c|}{ TS } & \multicolumn{2}{|c|}{ STS } & \multicolumn{2}{|c|}{ Amount } \\
\hline & $\mathbf{F}$ & $\%$ & $\mathbf{F}$ & $\%$ & $\mathbf{F}$ & $\%$ & $\mathbf{F}$ & $\%$ & $\mathbf{F}$ & $\%$ & $\mathbf{F}$ & $\%$ \\
\hline 1 & 6 & $9.5 \%$ & 35 & $55.6 \%$ & 22 & $34.9 \%$ & 0 & $0.0 \%$ & 7 & $0.0 \%$ & 63 & $100.0 \%$ \\
\hline 2 & 13 & $20.6 \%$ & 28 & $44.4 \%$ & 22 & $34.9 \%$ & 0 & $0.0 \%$ & U & $0.0 \%$ & 63 & $100.0 \%$ \\
\hline 3 & 30 & $47.6 \%$ & 23 & $36.5 \%$ & 10 & $15.9 \%$ & 0 & $0.0 \%$ & 0 & $0.0 \%$ & 63 & $100.0 \%$ \\
\hline 4 & 18 & $28.6 \%$ & 45 & $71.4 \%$ & 0 & $0.0 \%$ & 0 & $0.0 \%$ & 0 & $0.0 \%$ & 63 & $100.0 \%$ \\
\hline 5 & 13 & $20.6 \%$ & 28 & $44.4 \%$ & 22 & $34.9 \%$ & 0 & $0.0 \%$ & $\bar{c}$ & $0.0 \%$ & 63 & $100.0 \%$ \\
\hline 6 & 6 & $9.5 \%$ & 35 & $55.6 \%$ & 22 & $34.9 \%$ & 0 & $0.0 \%$ & 0 & $0.0 \%$ & 63 & $100.0 \%$ \\
\hline 7 & 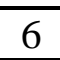 & $9.5 \%$ & 35 & $55.6 \%$ & 22 & $34.9 \%$ & 0 & $0.0 \%$ & - & $0.0 \%$ & 63 & $100.0 \%$ \\
\hline 8 & 18 & $28.6 \%$ & 45 & $71.4 \%$ & 0 & $0.0 \%$ & 0 & $0.0 \%$ & U & $0.0 \%$ & 63 & $100.0 \%$ \\
\hline 9 & 13 & $20.6 \%$ & 28 & $44.4 \%$ & 22 & $34.9 \%$ & 0 & $0.0 \%$ & 0 & $0.0 \%$ & 63 & $100.0 \%$ \\
\hline Average & 14 & $21.7 \%$ & 34 & $53.3 \%$ & 16 & $25.0 \%$ & 0 & $0 \%$ & 0 & $0 \%$ & 63 & $100.0 \%$ \\
\hline
\end{tabular}

Source: Research Results 2020

\subsection{Descriptive Statistics}

If the standard deviation value is greater than the mean value, it means that the mean value is a poor representation of the overall data. However, if the standard deviation value is smaller than the mean value, this means that the mean value can be used as a representation of the entire data. Descriptive statistics of each variable job satisfaction, quality of work life and work performance can be seen in the following.

\subsection{Descriptive Statistics on Job Satisfaction (X1)}

Table 7. Descriptive Statistics Test Results on Job Satisfaction (X1) Descriptive Statistics

\begin{tabular}{||l|r|r|r|r|r|r|r||}
\hline \hline & \multicolumn{1}{|c|}{$\mathrm{N}$} & Minimum & Maximum & \multicolumn{1}{c|}{ Sum } & \multicolumn{2}{|c||}{ mean } & Std. Deviation \\
\cline { 2 - 8 } & Statistics & Statistics & Statistics & Statistics & Statistics & Std. Error & \multicolumn{1}{c|}{ Statistics } \\
\hline Kp.Kerja & 63 & 4.00 & 5.00 & 266.00 & 4.2222 &, 05280 &, 41908 \\
Kp.Kerja & 63 & 3.00 & 5.00 & 255.00 & 4.0476 & 0.04190 &, 33256 \\
Kp.Kerja & 63 & 4.00 & 5.00 & 266.00 & 4.2222 &, 05280 &, 41908 \\
Kp.Kerja & 63 & 3.00 & 5.00 & 255.00 & 4.0476 & 0.04190 &, 33256 \\
Kp.Kerja & 63 & 3.00 & 5.00 & 255.00 & 4.0476 & 0.04190 &, 33256 \\
Kp.Kerja & 63 & 4.00 & 5.00 & 285.00 & 4,5238 &, 06343 &, 50344 \\
Kp.Kerja & 63 & 3.00 & 5.00 & 255.00 & 4.0476 & 0.04190 &, 33256 \\
Kp.Kerja & 63 & 3.00 & 5.00 & 255.00 & 4.0476 & 0.04190 &, 33256 \\
Kp.Kerja & 63 & 4.00 & 5.00 & 266.00 & 4.2222 &, 05280 &, 41908 \\
Total_X1 & 63 & 31.00 & 45.00 & 2358.00 & 37.4286 &, 29738 & 2.36039 \\
Valid N & 63 & & & & & & \\
(listwise) & & & & & & \\
\hline \hline
\end{tabular}

Source: SPSS Processing Results in 2020 
In table 7 above, the standard deviation value shows a value that is smaller than the mean $(2,36<37,42)$, this means that the mean value can be used as a representation of the entire data. Furthermore, a description of the statistical data from the 63 samples collected, the job satisfaction variable item has the lowest value of 31 and the highest value of 45 with a mean value of 37.42 . The overall average of the total job satisfaction variables is $(37.42 / 9)=4.15$, meaning that the average job satisfaction indicator variable has a good/high category.

\subsection{Descriptive Statistics on Quality of Work Life (X2)}

Table 8. Test results Descriptive Statistics on Quality of Work Life (X2)

Descriptive Statistics

\begin{tabular}{|c|c|c|c|c|c|c|c|}
\hline & \multirow{2}{*}{\begin{tabular}{|c|}
$\mathrm{N}$ \\
Statistics
\end{tabular}} & \multirow{2}{*}{$\begin{array}{l}\text { Minimum } \\
\text { Statistics }\end{array}$} & \multirow{2}{*}{$\begin{array}{l}\text { Maximum } \\
\text { Statistics }\end{array}$} & \multirow{2}{*}{$\begin{array}{c}\text { Sum } \\
\text { Statistics }\end{array}$} & \multicolumn{2}{|c|}{ mean } & $\begin{array}{c}\text { Std. } \\
\text { Deviation }\end{array}$ \\
\hline & & & & & Statistics & Std. Error & Statistics \\
\hline K.Keh.Work & 63 & 4.00 & 5.00 & 268.00 & 4.2540 & 0.05528 & ,43878 \\
\hline K.Keh.Work & 63 & 3.00 & 5.00 & 250.00 & 3.9683 & 0.08755 & ,69487 \\
\hline K.Keh.Work & 63 & 3.00 & 5.00 & 278.00 & 4.4127 & ,07379 & ,58571 \\
\hline K.Keh.Work & 63 & 4.00 & 5.00 & 265.00 & 4.2063 & 05139 & ,40793 \\
\hline K.Keh.Work & 63 & 4.00 & 5.00 & 265.00 & 4.2063 & 05139 & 40793 \\
\hline K.Keh.Work & 63 & 4.00 & 5.00 & 288.00 & 4.5714 & ,06285 & , 49885 \\
\hline K.Keh.Work & 63 & 3.00 & 5.00 & 262.00 & 4.1587 & 0.06074 & ,48214 \\
\hline K.Keh.Work & 63 & 4.00 & 5.00 & 265.00 & 4.2063 & 05139 & ,40793 \\
\hline K.Keh.Work & 63 & 4.00 & 5.00 & 288.00 & 4.5714 & ,06285 & , 49885 \\
\hline Total_X2 & 63 & 33.00 & 44.00 & 2429.00 & 38.5556 & ,30340 & 2.40817 \\
\hline $\begin{array}{l}\text { Valid N } \\
\text { (listwise) }\end{array}$ & 63 & & & & & & \\
\hline
\end{tabular}

Source: SPSS Processing Results in 2020

In table 8 above, the standard deviation value shows a value that is smaller than the mean $(2.40<38.55)$, this means that the mean value can be used as a representation of the entire data. Furthermore, a description of the statistical data from the 63 samples collected, itemsThe variable quality of work life has the lowest value of 33 and the highest value of 44 with a mean value of 38.55 . The overall average of the total variable quality of work life is $(38.55 / 9)=4.28$, meaning that the average indicator of the quality of work life variable has a categorygood/high.

\subsection{Descriptive Statistics on Work Performance (Y)}

Table 9. Test results Descriptive Statistics on Work Performance (Y)

Descriptive Statistics

\begin{tabular}{||l|r|r|r|r|r|r|r||}
\hline & \multicolumn{1}{|c|}{ N } & Minimum & Maximum & \multicolumn{1}{|c|}{ Sum } & \multicolumn{2}{|c||}{ mean } & $\begin{array}{c}\text { Std. } \\
\text { Deviation }\end{array}$ \\
\cline { 2 - 7 } & Statistics & Statistics & Statistics & Statistics & Statistics & $\begin{array}{c}\text { Std. } \\
\text { Error }\end{array}$ & Statistics \\
\hline Pres.Work & 63 & 3.00 & 5.00 & 236.00 & 3.7460 &, 07828 &, 62135 \\
Pres.Work & 63 & 3.00 & 5.00 & 243.00 & 3.8571 &, 09291 &, 73741 \\
Pres.Work & 63 & 3.00 & 5.00 & 272.00 & 4.3175 &, 09282 &, 73672
\end{tabular}




\begin{tabular}{||l|l|r|r|r|r|r|r||} 
Pres.Work & 63 & 4.00 & 5.00 & 270.00 & 4.2857 & 0.05737 &, 45538 \\
Pres.Work & 63 & 3.00 & 5.00 & 243.00 & 3.8571 &, 09291 &, 73741 \\
Pres.Work & 63 & 3.00 & 5.00 & 236.00 & 3.7460 &, 07828 &, 62135 \\
Pres.Work & 63 & 3.00 & 5.00 & 236.00 & 3.7460 &, 07828 &, 62135 \\
Pres.Work & 63 & 4.00 & 5.00 & 270.00 & 4.2857 & 0.05737 &, 45538 \\
Pres.Work & 63 & 3.00 & 5.00 & 243.00 & 3.8571 &, 09291 &, 73741 \\
Total_Y & 63 & 29,00 & 45.00 & 2249.00 & 35.6984 &, 49194 & 3.90465 \\
Valid N & 63 & & & & & & \\
(listwise) & & & & & & \\
\hline \hline
\end{tabular}

Source: SPSS Processing Results in 2020

In table 5.9 above, the standard deviation value shows a value that is smaller than the mean $(3.90<35.69)$, this means that the mean value can be used as a representation of the entire data. Furthermore, a description of the statistical data from the 63 samples collected, itemsThe work performance variable has the lowest value of 29 and the highest value of 45 with a mean value of 35.69. The overall average of the total indicators of the quality of work life variable is $(35.69 / 9)=3.96$, meaning that the average indicator of the quality of work life variable has a categorygood/high.

\subsection{Validity Test}

Table 10. Validity Test Results

\begin{tabular}{|c|c|c|c|c|}
\hline Variable & $\begin{array}{l}\text { No. } \\
\text { Items }\end{array}$ & $\begin{array}{c}(\mathrm{n}=63,=5 \%) \\
\quad(\text { rtable }))\end{array}$ & $\begin{array}{c}\text { Corrected item-total correlation } \\
(\text { rcount }))\end{array}$ & Conclusion \\
\hline \multirow[b]{9}{*}{ Job Satisfaction (X1) } & X 11 & 0.248 & 0.603 & Valid \\
\hline & X 12 & 0.248 & 0.795 & Valid \\
\hline & X 13 & 0.248 & 0.603 & Valid \\
\hline & X 14 & 0.248 & 0.795 & Valid \\
\hline & X 15 & 0.248 & 0.795 & Valid \\
\hline & X 16 & 0.248 & 0.555 & Valid \\
\hline & X 17 & 0.248 & 0.795 & Valid \\
\hline & X 18 & 0.248 & 0.795 & Valid \\
\hline & X 19 & 0.248 & 0.603 & Valid \\
\hline \multirow[b]{9}{*}{ Quality of Work Life (X2) } & X 21 & 0.248 & 0.490 & Valid \\
\hline & X 22 & 0.248 & 0.589 & Valid \\
\hline & X 23 & 0.248 & 0.521 & Valid \\
\hline & X 24 & 0.248 & 0.522 & Valid \\
\hline & X 25 & 0.248 & 0.522 & Valid \\
\hline & X 26 & 0.248 & 0.591 & Valid \\
\hline & X 27 & 0.248 & 0.520 & Valid \\
\hline & X 28 & 0.248 & 0.522 & Valid \\
\hline & X 29 & 0.248 & 0.591 & Valid \\
\hline \multirow[b]{3}{*}{ Work Performance (Y) } & Y1 & 0.248 & 0.566 & Valid \\
\hline & $\mathrm{Y} 2$ & 0.248 & 0.814 & Valid \\
\hline & Y 3 & 0.248 & 0.667 & Valid \\
\hline
\end{tabular}




\begin{tabular}{||c|c|c|c|c||}
\hline \multirow{7}{*}{} & Y 4 & 0.248 & 0.612 & Valid \\
\cline { 2 - 5 } & Y 5 & 0.248 & 0.814 & Valid \\
\cline { 2 - 5 } & Y 6 & 0.248 & 0.566 & Valid \\
\cline { 2 - 5 } & Y 7 & 0.248 & 0.566 & Valid \\
\cline { 2 - 5 } & Y 8 & 0.248 & 0.612 & Valid \\
\cline { 2 - 5 } & Y 9 & 0.248 & 0.814 & Valid \\
\hline
\end{tabular}

Source: SPSS Processing Results in 2020

The validity test was carried out by calculating the correlation between the scores of each statement item and the total score. From table 5.10 above, it can be seen that the correlation of all items for job satisfaction (X1), quality of work life (X2), work performance $(\mathrm{Y})$ shows the value ofr count $>$ from $r$ table(0.248) and is positive. Thus, it can be concluded that all statementsdeclared valid.

\subsection{Reliability Test}

To test the most frequently used reliability, most researchers use Crobach's Alpha. The value of a questionnaire declared reliable is usually defined with an alpha number of 0.60-0.80 which is good enough for basic research purposes.

Table 11. X and Y. Reliability Test Results

\begin{tabular}{||l|c|c|c||}
\hline \multicolumn{1}{|c|}{ Variable } & $\begin{array}{c}\text { Alpha } \\
\text { Value }\end{array}$ & Reliable/Unreliable & Conclusion \\
\hline Job Satisfaction (X1) & 0.856 & Reliable (High) & Worn \\
\hline Quality of Work Life (X2) & 0.689 & Reliable (Enough) & Worn \\
\hline Work Performance (Y) & 0.849 & Reliable (High) & Worn \\
\hline
\end{tabular}

Source: SPSS Processing Results in 2020

\subsection{Data Normality Test}

The normality test aims to test whether the residuals of the regression model studied are normally distributed or not. In this study, the normality test method used was the Kolmogorov-Smirnov test with the help of the Statistical Product and Service Solution (SPSS) for Windows.

Table 12. Normality Test Results

One-Sample Kolmogorov-Smirnov Test

\begin{tabular}{|c|c|c|}
\hline & & $\begin{array}{c}\text { Unstandardized } \\
\text { Residual }\end{array}$ \\
\hline \multicolumn{2}{|l|}{$\mathrm{N}$} & 63 \\
\hline \multirow{3}{*}{ Normal Parameters, b } & mean & $0 \mathrm{E}-7$ \\
\hline & Std. Deviation & 3.03246610 \\
\hline & Absolute & 0.060 \\
\hline \multirow[t]{2}{*}{ Most Extreme Differences } & Positive & 0.057 \\
\hline & negative &,- 060 \\
\hline Test Statistics & & 0.060 \\
\hline asymp. Sig. (2-tailed) & & ,200 \\
\hline
\end{tabular}

Source: SPSS Processing Results in 2020 
Table 12 above, shows that the Kolmogorov Smirnov test on the residual value in the Asymp.Sig row. (2-tailed) produces a significance value of $0.200>0.05$, based on these results, it is concluded that the residuals of the regression model are normally distributed, thus the assumption of normality of the residuals has been met and the data are normally distributed.

\subsection{Multicollinearity Test}

Multicollinearity testing aims to determine whether between variables are free to have a relationship with each other or not. Multicollinearity test is necessary done because the number of independent variables in this study amounted to more than one.The method for testing the presence or absence of multicollinearity can be seen in Tolerance Value and Inflation Factor (VIF). The tolerance value limit is 0.10 or the VIF value is 10 . If the tolerance value $>0.10$ and VIF $<10$ then multicollinearity does not occur and vice versa if the tolerance value $<0.10$ and VIF $>10$ then multicollinearity occurs. The processing results can be seen in table 5.13 below:

Table 13. Multicollinearity Test Results

Coefficients

\begin{tabular}{|c|c|c|c|c|c|c|}
\hline \multirow{2}{*}{\multicolumn{2}{|c|}{ Model }} & \multicolumn{3}{|c|}{ Correlations } & \multicolumn{2}{|c|}{ Collinearity Statistics } \\
\hline & & Zero-order & Partial & Part & Tolerance & VIF \\
\hline \multirow{3}{*}{1} & (Constant) & & & & & \\
\hline & Total_X1 &, 583 & ,429 & ,369 &, 721 & 1.386 \\
\hline & Total_X2 & ,510 & ,294 & ,239 & ,721 & 1.386 \\
\hline
\end{tabular}

Source: SPSS Processing Results in 2020

Based on table 13 above, it can be seen that the tolerance value of all variables free has a value greater than 0.10 and a VIF value is less than 10 then it can be concluded that there is no multicollinearity.

\subsection{Heteroscedasticity Test}

Heteroscedasticity test is carried out to determine whether in a regression model there is a similarity or dissimilarity of variance between one observation and another observation. If the variance of the residuals from one observation to another observation is still called homoscedasticity and if it is different it is called heteroscedasticity. A good regression model is a model that does not occur heteroscedasticity. Analyzing the data in testing this classical assumption, the researcher uses Statistical Product and Service Solution Program (SPSS) for Windows and can be seen in the following table 14

Table 14. Park Test Results

Coefficientsa

\begin{tabular}{|c|c|c|c|c|c|c|}
\hline \multirow{2}{*}{\multicolumn{2}{|c|}{ Model }} & \multicolumn{2}{|c|}{ Unstandardized Coefficients } & \multirow{2}{*}{$\begin{array}{c}\text { Standardized } \\
\text { Coefficients }\end{array}$} & \multirow[t]{2}{*}{$\mathrm{t}$} & \multirow[t]{2}{*}{ Sig. } \\
\hline & & B & Std. Error & & & \\
\hline \multirow{3}{*}{1} & (Constant) & $-4,876$ & 5.074 & &,- 961 & ,340 \\
\hline & Total_X1 & ,036 & , 139 & 039 &, 259 & ,796 \\
\hline & Total_X2 &, 115 & , 136 &, 128 &, 850 & 399 \\
\hline
\end{tabular}

Source: SPSS Processing Results in 2020 
Based on table 14 above, it can be seen that the park test produces a significance value of each independent variable $>0.05$, it is concluded that there is no heteroscedasticity in the regression model and thus the assumption of no heteroscedasticity has been fulfilled.

\subsection{Autocorrelation Test}

The autocorrelation test is used to determine the deviation of the classical assumption of autocorrelation, namely the correlation that occurs between the residuals in one observation with other observations in the regression model. A good regression model is that there is no autocorrelation. The approach used to test the presence or absence of autocorrelation is the Durbin-Watson test (DW test).

The Durbin-Watson test is only used for first-order autocorrelation and requires an intercept (constant) in the regression model and there are no other variables among the independent variables.

Table 15. Durbin-Watson Test Results (DW Test)

Model Summaryb

\begin{tabular}{|c|c|c|c|c|}
\hline \multirow[t]{2}{*}{ Model } & \multicolumn{3}{|c|}{ Change Statistics } & \multirow[t]{2}{*}{ Durbin-Watson } \\
\hline & df1 & $\mathrm{df} 2$ & Sig. F Change & \\
\hline 1 & $2 \mathrm{a}$ & 60 & ,000 & 1,688 \\
\hline
\end{tabular}

Source: SPSS Processing Results in 2020

Based on table 15 above, the Durbin-Watson value is 1.688. The Durbin-Watson value according to the table with $n=63$ respondents and $K=2$ (in this case the number of independent variables) obtained the numbers $\mathrm{dl}=1.527$ and $\mathrm{du}=1.658$. Therefore, the calculated DW value $>\mathrm{du}(1.688>1.658)$, it can be concluded that there is no autocorrelation in the regression model, so the model is feasible to use.

\section{Conclusion}

From the results of the analysis that has been discussed about " The Analysis of Quality of Work Life and Work Achievement in Dinas Pertanian Simalungun RegencyWith a total of 63 respondents, the following conclusions can be drawn:

1. Job satisfaction has a positive and significant effect on employee work performance in Simalungun Regency Agriculture Office.

2. Leaders are expected to improve the promotion appraisal system based on performance and work results.

3. Maintaining the current good condition of employees, who are able to work hard to get awards, a well-developed family atmosphere and the creation of an interesting and challenging work atmosphere. 


\section{References}

As'ad, Mohammad, (2014). Kepemimpinan efektif dalam Perusahaan, Suatu Pendekatan Psikologik. Edisi Kedua. Yogyakarta: Liberty

Astrianditya Januar Ristanti. (2016). Pengaruh Kualitas Kehidupan Kerja Dan Kepuasan Kerja Terhadap Kinerja Karyawan Pt Pertamina Persero Ru IV Cilacap, (Jurnal Akuntansi dan Pendidikan, Volume 5, Nomor 1, April).

Azwar. Saifuddin. (2013). Metode Penelitian. Yogyakarta: Pustaka Pelajar.

Cherrington, David J. (2010). The Management of Human Resources (4thEdition). New Jersey: Prentice Hall Inc.

Davis, Keith. (2010). Organizational Behavior-Human Behavior at Work 13th Edition. New Delhi: Mcgraw Hill Company.

Fabian Michele Paseki. (2013). "Kualitas Kehidupan Kerja dan Kinerja Karyawan Terhadap Pengembangan Karir pada Kanwil Direktorat Jenderal Kekayaan Negara Sulutenggo Malut di Manado,'Jurnal EMBA Vol.1, No.4 (Desember): 1242.

Hary Murti dan Veronika Agustini Srimulyani. (2013). Pengaruh Motivasi Terhadap Kinerja Pegawai Dengan Variabel Pemediasi Kepuasaan Kerja Pada PDAM Kota Madiun. Jurnal Riset Manajemen dan Akuntansi (JRMA). Vol. 1 No. 1, Februari 2013. pp. 10-17.

Hasibuan, Malayu S.P. (2016). Manajemen Sumber Daya Manusia. Jakarta: PT Bumi Aksara.

Husein, Umar. (2011). Metode Penelitian Untuk Skripsi dan Tesis Bisnis Edisi 11. Jakarta: PT Raja Grafindo Persada.

Ichsan, R. et al. (2021). Determinant of Sharia Bank's Financial Performance during the Covid-19 Pandemic. Budapest International Research and Critics Institute-Journal (BIRCI-Journal). P. 298-309.

Ivancevich, J.M., dan Matteson, M.T (2010). Organizational Behaviour and Management. Singapore: Irwin/McGraw-hill.

Kreitner, Robert dan Angelo Kinicki. (2014). Perilaku Organisasi. Jakarta: Salemba Empat.

Luthans, Fred. (2012). "Perilaku Organisasi”. Yogyakarta: Penerbit Andi.

Mangkunegara, Anwar Prabu. (2013). Manajemen Sumber Daya Manusia Perusahaan. Bandung: PT Remaja Rosdakarya.

Marihot Tua Effendi Hariandja. (2012). Managemant Sumber Daya Manusia Pengadaan Pengembangan, Pengkompensasian dan Peningkatan Produktivitas Pegawai, (Jakarta: PT Gramedia Widiasarana Indonesi), h. 292.

Milton, Friedman. (2010). The Social Responsibility of Business is to Increase its Profits. USA: The New York Time Company.

Priansa, D. J. (2010). Perencanaan \& Pengembangan SDM. Bandung: Alfabeta.

Priyatno, Duwi. (2012). Cara Kilat Belajar Analisis Data dengan SPSS 20. Yogyakarta: Andi Offset.

Rashmi Rai. (2015). "Does Quality of Work Life Have Effect on Job Performance?-A Study on Indian IT Professionals," SAMVAD: SIBM PUNE Research Journal, Vol X, 93-99, December.

Robbins, Stephen P. \& Judge, Timothy A. (2013). Perilaku Organisasi, buku 2. Jakarta: Salemba Empat.

Sugiyono. (2011) Metode Penelitian Kuantitatif dan Kualitatif dan R \& D.Bandung: CV Alfabeta. 
Wa Musi Lanudi, Herminawaty, Rafiuddin. (2020). "Pengaruh Kepuasan Kerja Dan Semangat Kerja Terhadap Prestasi Keja Pada Dinas Perkebunan Provinsi Selawasi Selatan", Economics Bosowa Journal Edisi XXXIV April s/d juni 2020 Vol 6, No. 002 WA musi lanudi.

Wirawan, (2015), Manajemen Sumber Daya Manusia Indonesia, Jakarta: Rajawali Pers.

Yosi Rizal, Akhmad Abdurrahman. (2020). "Pengaruh Motivasi, Disiplin Kerja, Dan Kepuasan Kerja Terhadap Prestasi Kerja Pegawai Pada Dinas Perumahan Rakyat, Kawasan Pemukiman Dan Lingkungan Hidup Hulu Sungai Selatan”, AdministrausJurnal Ilmu Administrasi Dan Manajemen Vol 4 No. 2 - Mei E-ISSN 2580-9695. 